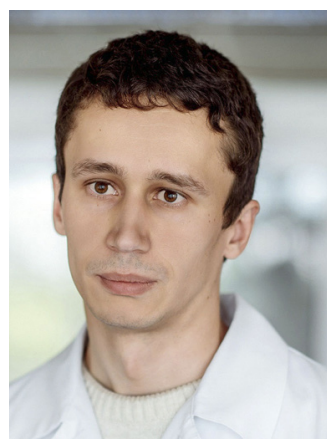

O. Katerenchuk, V. Zhdan, I. Katerenchuk

The Higher State Educational Institution of Ukraine

"Ukrainian Medical Stomatological Academy"

\title{
Diagnostic and Prognostic Value of Psycho-Autonomic Dysfunction as Factor of Ischemic Heart Failure Progression
}

Introduction. Cardiovascular diseases are the main cause of premature death in the structure of overall mortality in Ukraine. Coronary arteries disease (CAD) or, as it still usually named, ischemic heart disease is responsible as for the premature death in acute conditions (occurrence of acute coronary syndromes) as for premature death caused by progression of chronic heart failure (CHF). CHF reduces quality of life, provoking physical disability and mental disturbances (for example, depression and/or anxiety), requiring repetitive hospitalizations and permanent out-of-hospital medical care and so formatting needs in high financial expenses. The solution of this problem lays in adequate primary and secondary prophylaxis of heart function deterioration in patients with CAD by taking into account psycho-autonomic disturbances as markers of increased risk for $\mathrm{CHF}$ decompensating.

The pathophysiological mechanisms that lead to the occurrence and progression of psychosomatic disorders (in particular, depression) in patients with $\mathrm{CHF}$ coincide with the mechanisms of progression of the $\mathrm{CHF}$ syndrome per se. It's reasonable to classify them into somatic components (neuro-humoral systems deregulation, immune system dysfunction, systemic inflammation, cytokines toxicity, etc.), behavioral factors (semi-attitude to own health, level of education, social atmosphere) and mechanisms of genetic predisposition $[4,5]$.

Several studies showed that the prevalence of depressive disorders among patients with CHF is in range of 14.0$60.0 \%[3,6]$. In the Heart Failure Adherence and Retention Trial (HART) depression was detected in one third of patients from the total number of participants; its presence was associated with lack of motivation to follow the recommendations of $\mathrm{CHF}$ treatment [8]. Also, psychosomatic disturbances are independent contributions to reducing quality of life $[2,7,11]$. It is important to note that the high prevalence of symptoms of depression was found not only among patients with clear clinical symptoms of
CHF, but also among the patients with asymptomatic left ventricular dysfunction $[9,10]$.

There are no doubt that psychosomatic disturbances significantly alter the natural course of ischemic CHF making clinical signs and symptoms less clear, the definition of diagnosis more difficult, complicating treatment and rehabilitation processes. So we need deep understanding of lying desadaptation processes in CHF. Usually it requires fundamentally complex approaches based on simultaneous correction of psychoautonomic dysfunction, neuro-humoral desadaptation, fluid balance normalization and so on. We have to focus our scientific interest on estimation of psychoautonomic dysfunction as factor of CHF progression with further implementation of achieved results into clinical practice.

The aim of the study. To evaluate the diagnostic and predictive value of psycho-autonomic dysfunction as factor of chronic heart failure progression in patients with coronary arteries disease.

Material and methods. 151 patients (60 males, 91 females; average age - $60 \pm 9,39$ years) were enrolled to the study after they previously signed an Informed consent for the complex diagnostic evaluation in accordance with the principles of Helsinki Declaration of Human Rights, The Convention on Human Rights and Biomedicine of Council of Europe and with the relevant laws of Ukraine.

The symptoms of anxiety and depression were evaluated by using Hospital Anxiety and Depression Scale. Result of $\geq 8$ points on each sub-scale was decided as clinically significant presentation of psychosomatic misbalance.

The evaluation of the state of tonic autonomic regulation was performed using Fazagraf ${ }^{\circledR}$ device and Fazagraf-M $\AA$ software based on heart rate variability analysis. The methodology for recording and interpreting the results of heart rate variability was based on the "Special Report of the Working Group of the European 
Cardiology Society and the North American Society for Pacing and Electrophysiology. The Heart Rate Variability. Standards of Measurement, Physiological Interpretation and Clinical Use" [1].

All participants were divided into 4 experimental groups. The first group $(n=35)$ was presented by the patients with excessive sympathetic tone and psychosomatic disorders (depression and/or anxiety); the second group $(n=18)$ was presented by patients having excessive sympathetic tone but without psychosomatic deteriorations; third group $(n=35)$ was presented with patients with the presence of psychosomatic disorders and normal autonomic tonic regulation; the fourth group $(n=63)$ named "control group" was formed of patients with normal autonomic tonic regulation and absence of anxiety and depression.

Studied groups did not differ from the control over the gender, age distribution, comorbid conditions and concomitant therapy (Table 1).

Table 1

The comparison of study groups with control group by gender, age and comorbid conditions

\begin{tabular}{|c|c|c|c|c|}
\hline \multirow[b]{2}{*}{ Parameter } & \multicolumn{4}{|c|}{ Studied groups } \\
\hline & $\begin{array}{l}\text { I - psycho - } \\
\text { autonomic } \\
\text { dysfunctions } \\
(n=35)\end{array}$ & \begin{tabular}{|c|} 
II - solid \\
autonomic \\
dysfunction \\
$(n=18)$
\end{tabular} & $\begin{array}{c}\text { III - solid } \\
\text { psychosomatic } \\
\text { dysfunction } \\
(n=35)\end{array}$ & $\begin{array}{c}\text { IV - control } \\
(n=63)\end{array}$ \\
\hline Age, years & $\begin{array}{c}61.74 \pm 9.07 \\
t=0.73 \\
p>0.05\end{array}$ & $\begin{array}{c}61.11 \pm 9.31 \\
t=0.31 \\
p>0.05\end{array}$ & $\begin{array}{c}59.66 \pm 9.55 \\
t=0.33 \\
p>0.05\end{array}$ & $60.32 \pm 9.69$ \\
\hline Gender, $\mathrm{m} / \mathrm{f}$ & $\begin{array}{c}12 / 23 \\
p=0.394\end{array}$ & $\begin{array}{c}9 / 9 \\
p=0.790\end{array}$ & $\begin{array}{c}14 / 21 \\
p=0.832\end{array}$ & $28 / 35$ \\
\hline Hypertension & $\begin{array}{c}34(97.14 \%) \\
p=0.416\end{array}$ & $\begin{array}{c}16(88.89 \%) \\
p=1.000\end{array}$ & $\begin{array}{c}30(85.71 \%) \\
p=0.487\end{array}$ & $58(92.06 \%)$ \\
\hline $\begin{array}{l}\text { Myocardial } \\
\text { infarction in the } \\
\text { past }\end{array}$ & $\begin{array}{c}14(40.00 \%) \\
p=0.665\end{array}$ & $\begin{array}{c}8(44.44 \%) \\
p=0.581\end{array}$ & $\begin{array}{c}13(37.14 \%) \\
p=1.000\end{array}$ & $22(34.92 \%)$ \\
\hline $\begin{array}{l}\text { Stroke in the } \\
\text { past }\end{array}$ & $\begin{array}{l}3(8.57 \%) \\
p=0.741\end{array}$ & $\begin{array}{l}1(5.56 \%) \\
p=0.676\end{array}$ & $\begin{array}{c}3(8.57 \%) \\
p=0.741\end{array}$ & $8(12.70 \%)$ \\
\hline $\begin{array}{l}\text { Heart valves } \\
\text { dysfunction }\end{array}$ & $\begin{array}{c}9(25.71 . \%) \\
p=0.618\end{array}$ & $\begin{array}{c}4(22.22 \%) \\
p=1.000\end{array}$ & $\begin{array}{c}17(48.57 \%) \\
p=0.006\end{array}$ & $13(20.63 \%)$ \\
\hline $\begin{array}{l}\text { Diabetes } \\
\text { mellitus }\end{array}$ & $\begin{array}{c}9(25.71 \%) \\
p=0.162\end{array}$ & $\begin{array}{c}2(11.11 \%) \\
p=1.000\end{array}$ & $\begin{array}{c}2(5.71 \%) \\
p=0.486\end{array}$ & $8(12.70 \%)$ \\
\hline
\end{tabular}

At the same time, all the study groups, compared with the control group, were characterized by the greater number of patients with more pronounced level of functional incapability and congestive form of CHF. But the groups I, II and III did not differ in functional class of angina $\left(\chi^{2}=0.540 ; p=0.763\right)$, in functional class of CHF $\left(\chi^{2}=0.100 ; p=0.950\right)$, and in the stage of CHF $\left(\chi^{2}=0.01 ; p=0.995\right)$. At the same time, the groups I, II and III were significantly different from the control group on functional class of angina $\left(\chi^{2}=\right.$ 14.54; $p<0.0001)$, functional class of CHF $\left(\chi^{2}=14.14\right.$; $p<0.0001)$ and on the stage of CHF $\left(\chi^{2}=15,01 ; p<\right.$ $0.0001)$. The obtained result indicates that the presence of autonomic and/or psychosomatic dysfunction is more typical for patients with significantly more severe forms of CHF (Table 2).

Table 2

The comparison of study groups with control group depending on the functional class of angina, functional class and stage of chronic heart failure

\begin{tabular}{|c|c|c|c|c|}
\hline \multirow[b]{2}{*}{ Parameter } & \multicolumn{4}{|c|}{ Studied groups } \\
\hline & $\begin{array}{l}\text { I - psycho - } \\
\text { autonomic } \\
\text { dysfunctions } \\
(n=35)\end{array}$ & $\begin{array}{c}\text { II - solid } \\
\text { autonomic } \\
\text { dysfunction } \\
(n=18)\end{array}$ & $\begin{array}{c}\text { III - solid } \\
\text { psychosomatic } \\
\text { dysfunction } \\
(n=35)\end{array}$ & $\begin{array}{c}\text { IV - control } \\
(n=63)\end{array}$ \\
\hline $\begin{array}{c}\text { Angina class } \\
\text { I-II } \\
\text { III-IV }\end{array}$ & $\begin{array}{l}12(34.29 \%) \\
23(65.71 \%)\end{array}$ & $\begin{array}{c}7(38.89 \%) \\
11(61.11 \%)\end{array}$ & $\begin{array}{l}15(42.86 \%) \\
20(57.14 \%)\end{array}$ & $\begin{array}{c}45(71.43 \%) \\
18(28.57 \%) \\
\chi^{2}=16.34 ; \\
p<0.0001\end{array}$ \\
\hline $\begin{array}{c}\text { CHF class: } \\
\text { I-II } \\
\text { III-IV }\end{array}$ & $\begin{array}{l}17(48.57 \%) \\
18(51.43 \%)\end{array}$ & $\begin{array}{l}9(50.00 \%) \\
9(50.00 \%)\end{array}$ & $\begin{array}{l}16(45.71 \%) \\
19(54.29 \%)\end{array}$ & $\begin{array}{c}50(79.37 \%) \\
13(20.63 \%) \\
\chi^{2}=15.55 ; \\
p<0.0001\end{array}$ \\
\hline $\begin{array}{c}\text { CHF stage } \\
\text { I } \\
\text { IIA-IIB }\end{array}$ & $\begin{array}{l}14(40.00 \%) \\
21(60.00 \%)\end{array}$ & $\begin{array}{c}7(38.89 \%) \\
11(61.11 \%)\end{array}$ & $\begin{array}{l}14(40.00 \%) \\
21(60.00 \%)\end{array}$ & $\begin{array}{c}46(73.02 \%) \\
17(26.98 \%) \\
\chi^{2}=16.32 ; \\
p<0.0001\end{array}$ \\
\hline
\end{tabular}

The general clinical and laboratory-instrumental examinations were performed in accordance with the European Society of Cardiologists recommendations and local clinical protocols. Exertional stress-tests (6-minutes walking test, treadmill) were performed to evaluate the functional class of CHF. Bicycle ergometry was performed using "Corival" (Lode, Netherlands) device, R. Bruce protocol.

The criteria of CHF progression were analyzed in 3and 6-month follow-up period:

1. Death due to the progression of CHF;

2. Hospitalization to the hospital or needs to refer to the hospital for medical treatment of heart failure decompensation, manifested by the appearance or increasing typical signs (worsening of NYHA class for CHF, worsening in shortness of breathing, the appearance of dyspnea in the rest, reduced tolerance to physical exertions, the occurrence of cardiac asthma episodes or signs of cardiogenic shock, the occurrence of arrhythmic events) that required parenteral drug administration;

3. Progression of dyspnea with deterioration of NYHA class;

4. Occurrence or increasing of clinical signs of congestion (edema, pleural effusion);

5. Changes in body weight due to the fluid retention (>2.0 kg per month);

6. Needs in initiation or intensification of medication therapy by using loop diuretics and/or vasodilators and/or cardiac glycosides.

Statistical analysis was performed using Statistica 6.0 version with the calculation of the mean arithmetic values and standard deviation, share (\%) with the average error of the relative index. The verification of the presence of normal distribution was carried out by using the A. Kolmogorov - N. Smirnov test. The comparison of two samples containing continuous variables was performed by applying the Student's t-test. 
Comparison of samples containing relative values was carried out by constructing the relative tables and calculating the $\chi^{2} \mathrm{~K}$. Pearson index. In the case of constructing tables of $2 \times 2$, the calculation of the $\chi^{2}$ index was supplemented by applying of the F. Yates correction for continuity. Due to the impossibility of applying the criterion $\chi^{2}$ (inadmissible values of expected numbers), the calculation was performed using the exact R. Fisher test $(p)$.

All patients who participated in the study were monitored throughout the 6-months period. The calculation of relative risk and its standard error was performed by constructing a quadruple table based on the number of cases (patients) that have certain factors and occurrence of clinical outcome events. In order to determine the statistical significance of the relative risk value $95 \%$ confidence interval [IC 95\%] was calculated. The results were considered statistically significant at the obtained value of $p<0,05$.

Results. The presence of combined psycho-autonomic imbalance was characterized by the statistically significant increased relative risk for occurrence of all signs of CHF progression (exception only for hospitalizations) compared with the control group in 3-months period of observation. No deaths were reported during the observational period. Thus, the relative risk for progression of shortness of breath and NYHA class worsening was evaluated as 2,472 [1.553-3.935; IC 95\%], progression of edema with an increase in the stage of CHF and increase in body weight due to congestion - 2.328 [1.412-3.837; IC $95 \%$ ], initiation of more aggressive medical therapy - 1.778 [1.051-3.007; IC $95 \%]$. The presence of isolated tonic hypersympathetic exertion resulted in a relative risk of edema progression at the level of 4.269 [2.262-8.059; IC $95 \%$ ], increase in body weight due to congestion - 4.066 [2.059-8.030; IC 95\%], for dyspnea progression and NYHA class worsening - 3.040 [1.303-7.093; IC 95\%]. The presence of isolated psychosomatic imbalances led to a statistically significant greater relative risk for the progression of edema and the stage of CHF - 2.328 [1.412-3.837; IC 95\%] as well as for progression of breathing shortness with the increase of CHF NYHA class - 2.328 [1.412-3.837; IC $95 \%$ ] (Table 3).

During the 6-months observational period the following data were obtained. In the group with solid psychosomatic disorders the relative risk did not have statistically significant differences compared to the control group. In the group of patients with solid tonic sympathetic exertion the relative risk was higher for progression of shortness of breath and CHF NYHA class, edema and CHF stage worsening and for the increasing needs for more aggressive therapy. At the same time related risk for the signs of CHF progression in 6-months period was lower in comparison to the relative risk in 3 -months period. It possibly can be explained by better patient compliance to the recommendations for regular aerobic exercise. At the same time, the presence of combined psycho-autonomic imbalance during the 6-months period of observation resulted in statistically significant increased relative risk for all parameters of CHF progression, even with the slight increase compared to the relative risk in the 3 -months period (Table 4).

Table 3

The relative risk for signs of chronic heart failure progression in studied group during 3 months-period of observation.

\begin{tabular}{|c|c|c|c|}
\hline \multirow[b]{2}{*}{$\begin{array}{l}\text { Sign of CHF } \\
\text { progression }\end{array}$} & \multicolumn{3}{|c|}{ Studied groups } \\
\hline & $\begin{array}{l}\text { I - psycho - } \\
\text { autonomic } \\
\text { dysfunctions } \\
(n=35)\end{array}$ & $\begin{array}{c}\text { II - solid } \\
\text { autonomic } \\
\text { dysfunction } \\
(n=18) \\
\end{array}$ & $\begin{array}{c}\text { III - solid } \\
\text { psychosomatic } \\
\text { dysfunction } \\
(n=35)\end{array}$ \\
\hline $\begin{array}{l}\text { Shortness } \\
\text { of breath and } \\
\text { NYHA class } \\
\text { worsening }\end{array}$ & $\begin{array}{l}2.472 \pm 0.237 \\
{[1.553-3.935]}\end{array}$ & $\begin{array}{l}3.040 \pm 0.432 \\
{[1.303-7.093]}\end{array}$ & $\begin{array}{l}2.328 \pm 0.255 \\
{[1.412-3.837]}\end{array}$ \\
\hline $\begin{array}{l}\text { Edema and CHF } \\
\text { stage worsening }\end{array}$ & $\begin{array}{l}2.328 \pm 0.255 \\
{[1.412-3.837]}\end{array}$ & $\begin{array}{l}4.269 \pm 0.324 \\
{[2.262-8.059]}\end{array}$ & $\begin{array}{l}2.472 \pm 0.237 \\
{[1.553-3.935]}\end{array}$ \\
\hline $\begin{array}{l}\text { Congestion } \\
\text { resulted in body } \\
\text { weight increase }\end{array}$ & $\begin{array}{l}2.328 \pm 0.255 \\
{[1.412-3.837]}\end{array}$ & $\begin{array}{l}4.066 . \pm .0 .347 \\
{[2.059-8.030]}\end{array}$ & $\begin{array}{l}1.424 \pm 0.519 \\
{[0.515-3.941]}\end{array}$ \\
\hline $\begin{array}{l}\text { Initiation of } \\
\text { more aggressive } \\
\text { therapy }\end{array}$ & $\begin{array}{l}1.778 \pm 1.778 \\
{[1.051-3.007]}\end{array}$ & $\begin{array}{l}1.273 \pm 0.543 \\
{[0.439-3.689]}\end{array}$ & $\begin{array}{l}1.090 \pm 0.380 \\
{[0.517-2.296]}\end{array}$ \\
\hline $\begin{array}{l}\text { Hospitalization } \\
\text { or referral } \\
\text { to hospital }\end{array}$ & $\begin{array}{l}1.467 \pm 0.349 \\
{[0.740-2.908]}\end{array}$ & $\begin{array}{l}1.321 \pm 0.637 \\
{[0.637-0.379]}\end{array}$ & $\begin{array}{l}1.055 \pm 0.478 \\
{[0,413-2,692]}\end{array}$ \\
\hline
\end{tabular}

Table 4

The relative risk for signs of chronic heart failure progression in studied groups during 6 months-period of observation

\begin{tabular}{|c|c|c|c|}
\hline \multirow[b]{2}{*}{$\begin{array}{l}\text { Sign of CHF } \\
\text { progression }\end{array}$} & \multicolumn{3}{|c|}{ Studied groups } \\
\hline & $\begin{array}{l}\text { I - psycho - } \\
\text { autonomic } \\
\text { dysfunctions } \\
(n=35)\end{array}$ & $\begin{array}{c}\text { II - solid } \\
\text { autonomic } \\
\text { dysfunction } \\
(n=18)\end{array}$ & $\begin{array}{c}\text { III - solid } \\
\text { psychosomatic } \\
\text { dysfunction } \\
(n=35)\end{array}$ \\
\hline $\begin{array}{l}\text { Shortness of breath } \\
\text { and NYHA class } \\
\text { worsening }\end{array}$ & $\begin{array}{l}3.658 \pm 0.274 \\
{[2.137-6.261]}\end{array}$ & $\left.\mid \begin{array}{l}2.585 \pm 0.395 \\
{[1.192-5.605]}\end{array}\right]$ & $\begin{array}{l}1.663 \pm 0.273 \\
{[0.973-2.842]}\end{array}$ \\
\hline $\begin{array}{l}\text { Edema and CHF } \\
\text { stage worsening }\end{array}$ & $\begin{array}{l}3.118 \pm 0.227 \\
{[2.000-4.863]}\end{array}$ & $\left|\begin{array}{l}3.550 \pm 0.369 \\
{[1.724-7.312]}\end{array}\right|$ & $\begin{array}{l}1.452 \pm 0.382 \\
{[0.686-3.071]}\end{array}$ \\
\hline $\begin{array}{l}\text { Initiation of more } \\
\text { aggressive therapy }\end{array}$ & $\begin{array}{l}3.800 \pm 0.388 \\
{[1.931-7.478]}\end{array}$ & $\left.\mid \begin{array}{l}3.500 \pm 0.388 \\
{[1.635-7.492]}\end{array}\right]$ & $\begin{array}{l}1.663 \pm 0.273 \\
{[0.973-2.842]}\end{array}$ \\
\hline $\begin{array}{l}\text { Congestion resulted } \\
\text { in body weight } \\
\text { increase }\end{array}$ & $\begin{array}{l}2.925 \pm 0.232 \\
{[1.856-4.609]}\end{array}$ & $\left|\begin{array}{l}1.825 \pm 0.511 \\
{[0.670-4.970]}\end{array}\right|$ & $\begin{array}{l}1.055 \pm 0.478 \\
{[0.413-2.692]}\end{array}$ \\
\hline $\begin{array}{l}\text { Hospitalization or } \\
\text { referral to hospital }\end{array}$ & $\begin{array}{l}1.778 \pm 0.274 \\
{[1.039-3.041]}\end{array}$ & $\left|\begin{array}{l}1.360 \pm 0.415 \\
{[0.603-3.066]}\end{array}\right|$ & $\begin{array}{l}0.955 \pm 0.300 \\
{[0.530-1.720]}\end{array}$ \\
\hline
\end{tabular}

\section{Conclusions:}

1. The presence of combined psycho-autonomic imbalance is associated with the highest relative risk of progression of chronic heart failure in the 6-months period with the strong tendency to increase over the time, despite the given recommendations to patients to follow life mode modification and pharmacological treatment.

2 . The presence of isolated tonic hypersympathetic exertion in the absence of psychosomatic disorders 
leads to the increased risk of signs of chronic heart failure progression in 3-and 6-months periods but not increases the relative risk of hospitalizations.

3 . The presence of psychosomatic disorders in the absence of hypersympathetic exertion is associated with decreasing relative risk of chronic heart failure progression in 6-months period possibly due to better compliance for life mode modification (especially for regular aerobic exercise) and optimal pharmacological treatment of chronic heart failure.

\section{References}

1. Heart rate variability: standards of measurement, physiological interpretation and clinical use. Task Force of the European Society of Cardiology and the North American Society of Pacing and Electrophysiology. Circulation. 1996;93(5):10431065. https://doi.org/10.1161/01.CIR.93.5.1043

2. Faller H, Steinbüchel T, Störk S, Schowalter M, Ertl G, Angermann CE. Impact of depression on quality of life assessment in heart failure. Int J Cardiol. 2010;142(2):133-137. https://doi.org/10.1016/j.ijcard.2008.12.093

3. Lossnitzer N, Herzog W, Störk S, Wild B, Müller-Tasch T, Lehmkuhl E et al. Incidence rates and predictors of major and minor depression in patients with heart failure. Int J Cardiol. 2013;167(2):502-507. https://doi.org/10.1016/j. ijcard.2012.01.062

4. Jiang W, Krishnan RR, O'Connor CM. Depression and heart disease: evidence of a link, and its therapeutic implications. CNS Drugs. 2002;16(2):111-127. https://doi.org/10.2165/00023210-200216020-00004

5. Joynt KE, Whellan DJ, O'connor CM. Why is depression bad for the failing heart? A review of the mechanistic relationship between depression and heart failure. J Card Fail. 2004;10(3):258-271. https://doi.org/10.1016/j.cardfail.2003.09.008

6. Thombs BD, Bass EB, Ford DE, Stewart KJ, Tsilidis KK, Patel U et al. Prevalence of depression in survivors of acute myocardial infarction. J Gen Intern Med. 2006;21(1):30-38. https://doi.org/10.1111/j.1525-1497.2005.00269.x

7. Jaarsma T, Johansson P, Agren S, Strömberg A. Quality of life and symptoms of depression in advanced heart failure patients and their partners. Curr Opin Support Palliat Care. 2010;4(4):233-237. https://doi.org/10.1097/SPC.0b013e328340744d

8. de Leon CF, Grady KL, Eaton C, Rucker-Whitaker C, Janssen I, Calvin J et al. Quality of life in a diverse population of patients with heart failure: Baseline findings from the heart failure adherence and retention trial (HART). J Cardiopulm Rehabil Prev. 2009;29(3):171-178. https://doi.org/10.1097/HCR.0b013e31819a0266

9. Lang RM, Badano LP, Mor-Avi V, Afilalo J, Armstrong A, Ernande L et al. Recommendations for cardiac chamber quantification by echocardiography in adults: an update from the American Society of Echocardiography and the European Association of Cardiovascular Imaging. J Am Soc Echocardiogr. 2015;28(1):1-39. https://doi.org/10.1016/j.echo.2014.10.003

10. Kim YH, Kim SH, Lim SY, Cho GY, Baik IK, Lim HE et al. Relationship between depression and subclinical left ventricular changes in the general population. Heart. 2012; Sep;98(18):1378-1383. https://doi.org/10.1136/heartjnl-2012-302180

11. Szyguła-Jurkiewicz B., Duszańska A., Poloński L. Is depression a problem in patients with chronic heart failure? Pol. Arch. Med. Wewn. 2008;118(1-2):52-56.

Стаття надійшла до редакції журналу 1 листопада 2017 р.

\section{Діагностичне і прогностичне значення психовегетативної дисфункції як чинника наростання важкості ішемічної серцевої недостатності}

\section{О. І. Катеренчук, В. М. Ждан, І. П. Катеренчук}

Вступ. Патофізіологічні механізми, що призводять до виникнення вегетативного дисбалансу та психосоматичних порушень (зокрема, депресії) у хворих із хронічною серцевою недостатністю (XCH), поєднуються з механізмами наростання важкості власне синдрому XCH та зумовлюють зростання ризику виникнення епізодів декомпенсації.

Результати новітніх досліджень у галузі базових наук підтверджують важливу роль вегетативної та психосоматичної дисфункції (зокрема, депресивних і тривожних порушень) не лише як маркерів важкості ХСН та коморбідних станів, але й як незалежних чинників наростання цього синдрому, що зумовлено наявністю спільних патофізіологічних (гемоциркулярних, нейрогуморальних, імунозапальних, цитотоксичних) механізмів розвитку. Морфофункціональні порушення в структурах центральної нервової системи (лімбіко-ретикулярний комплекс, довгастий мозок, префронтальна ділянка кори) $є$ патофізіологічною основою формування причинно-наслідкового поєднання вегетативних і психосоматичних дисфункцій 3 власне прогресуванням ішемічної хвороби серця та ХCH.

Мета. 3'ясувати діагностичну та прогностичну роль поєднаної психовегетативної дисфункції щодо наростання важкості ХСН у хворих на ішемічну хворобу серця.

Матеріали й методи. Оцінюючи варіабельність серцевого ритму діагностичним комплексом «Фазаграф», з'ясовували стан вегетативної тонічної активності. Психосоматичний дисбаланс вивчали, заповнюючи Шпитальну шкалу депресії і тривожності. Відносний ризик визначали за допомогою побудови чотирипольних таблиць.

Результати. У дослідження включено 151 хворого (60 чоловіків, 91 жінка; середній вік - 60 $\pm 9,31$ року). Пацієнтів поділено на чотири групи залежно від наявності ізольованих або поєднаних вегетативних і психосоматичних порушень. У 3- і 6-місячний період оцінювали поширення виникнення ознак декомпенсації серцевої недостатності. Виявлено, що наявність вегетативної i/або психосоматичної дисфункції асоціюється 
3 вищим функціональним класом стенокардії навантаження, вищим функціональним класом і стадією серцевої недостатності. Вивчення відносного ризику наростання важкості серцевої недостатності в 3- і 6-місячний період показало, що найгірший прогностичний профіль $є$ в разі поєднаної вегетативної та поєднаної психовегетативної дисфункції, в 6-місячний період - поєднаної психовегетативної дисфункції з істотним зростанням відносного ризику в часі.

Висновки. За наявності комбінованого психовегетативного дисбалансу існує найбільший відносний ризик наростання важкості хронічної серцевої недостатності упродовж 6 місяців із потужною тенденцією до збільшення протягом усього цього періоду, незважаючи на рекомендації, що надаються пацієнтам для модифікації способу життя і дотримання медикаментозного лікування. За наявності ізольованої гіперсимпатикотонії (за відсутності психосоматичних розладів) підвищується ризик виникнення ознак хронічної серцевої недостатності впродовж 3- і 6-місячного періоду, але не зростає відносний ризик щодо шпиталізації. Психосоматичні розлади за відсутності гіперсимпатикотонії супроводжуються зниженням відносного ризику наростання важкості хронічної серцевої недостатності впродовж 6 місяців.

Ключові слова: серцева недостатність, ішемічна хвороба серця, вегетативна дисфункція, психосоматична дисфункція, відносний ризик.

\section{Diagnostic and Prognostic Value of Psycho-Autonomic Dysfunction as Factor of Ischemic Heart Failure Progression}

\section{O. Katerenchuk, V. Zhdan, I. Katerenchuk}

Introduction. Coronary arteries disease or, as it still often named, ischemic heart disease is responsible as for premature death in acute conditions (occurrence of acute coronary syndromes) as for premature death caused by progression of chronic heart failure (CHF) of ischemic etiology.

The pathophysiological mechanisms that lead to the occurrence and progression of psychosomatic and autonomic disorders (in particular, depression) in patients with CHF coincide with the mechanisms of progression of the syndrome of CHF per se.

The solution of this problem lays in adequate primary and secondary prophylaxis of heart function deterioration in patients with coronary arteries disease by taking into account psycho-autonomic disturbances that should be used as markers of increased risk for heart failure decompensation.

Aim. To evaluate the diagnostic and predictive value of psycho-autonomic dysfunction as factor of CHF progression in patients with coronary arteries disease.

Materials and methods. The state of autonomic tonic activity was evaluated by analyzing the heart rate variability using the diagnostic complex Fasagraf. Psychosomatic misbalance was estimated by filling the Hospital Anxiety and Depression Scale. The calculation of relative risk was carried out by constructing four-squared tables.

Results. The study included 151 patients, divided into 4 groups, depending on the presence of isolated or combined vegetative and psychosomatic disorders. In 3 and 6-month periods, the occurrence of signs of decompensation of heart failure was assessed.

The presence of the combined psycho-autonomic imbalance was characterized by the statistically significant increase in relative risk for occurrence of all signs of CHF progression (exception only for hospitalizations) compared with the control group in 3-months period of observation.

The presence of isolated tonic hypersympathetic exertion resulted in elevated relative risk of edema progression, increasing body weight due to congestion, for dyspnea progression and NYHA class worsening. The presence of isolated psychosomatic imbalances led to the statistically significant greater relative risk for the progression of edema and the stage of CHF and for progression of shortness of breathing with the increase of CHF NYHA class.

The presence of combined psycho-autonomic imbalance during the 6-month period of observation resulted in statistically significant increased relative risk for all parameters of CHF progression, even with the slight increase of it compared to the relative risk in the 3-months period.

In the group with solid psychosomatic disorders, the relative risk did not have statistically significant differences compared to the control group. In the group of patients with solid tonic sympathetic exertion tone the relative risk was higher for progression of shortness of breathing and CHF NYHA class, edema and CHF stage worsening and for the increasing needs for the more aggressive therapeutic tactic.

Conclusions. The presence of combined psycho-autonomic disorders or tonic isolated hypersympathetic state causes the increased risk of CHF progression in 3- and 6-months periods. The presence of isolated psychosomatic disorders is characterized by the decrease in the relative risk of progression of dyspnea, edematous syndrome, NYHA functional class and the stage of heart failure during 6-months follow-up period due to the regular aerobic exercises and optimal pharmacological treatment.

Keywords: heart failure, ischemic heart disease, autonomic dysfunction, psychosomatic dysfunction, relative risk. 